\title{
Editorial
}

Kia ora and welcome to the fifth issue of Backstory. We have finished 2018 with a varied collection of articles on topics that range from a Māori mobile phone game to urban art in post-earthquake Christchurch via risqué cabarets in London during the early 1940s. The history of New Zealand's art, media, and design is full of surprising and untold stories that illuminate the country's past from new and revealing perspectives. This issue of Backstory gives an idea of the range of this research. Photography in New Zealand goes back to at least 1848 when the first daguerreotypes were made and photography shops were established in Auckland and Wellington. Athol McCredie analyses the history and role of the photograph book, or 'photobook' in New Zealand. Not to be confused with an album stuffed full of random snaps, McCredie discusses the idea of the photobook as an ordered narrative that is quite different from a book of photographs. He traces a prehistory of the photobook in New Zealand before the modern usage of the term and analyses examples and case studies to illustrate how the photobook has been part of New Zealand's photographic history.

Photographs, drawings, and illustrations have been integral to the New Zealand School Journal since it was launched in 1907. Many famous local artists and artists have contributed to the NZSJ over fifty years or so. This piece highlights the sheer variety of the forms, styles, and material found in the NZSJ as it reflects the vast and ongoing social and cultural changes since the 1960s.

That infamous decade, the 1960s, is often regarded as a watershed for revolutionary changes to ideas about gender and sexuality. But Alan Cocker's article complicates this sometime simplistic narrative by looking further back to the careers of Huia and Desiree Cooper in the cabarets and nude-revues of wartime London. Originally from Eltham, the successful careers of the Cooper sisters reflected cultural shifts in ideas about gender and the growth of media influence that had occurred in the years following World War One.

The Cooper girls were reported on proudly in Taranaki as local girls who made it on the London stage. New Zealand has not always been so proud of local culture especially its popular music. For many years local music fans and institutions often seemed slightly embarrassed by New Zealand popular music. This changed during the late 1980s. Matt Mollgaard traces this birth of the cool for New Zealand pop music as it was written in print publications from John Dix's Stranded in Paradise (1988) to Chris Bourke's Blue Smoke (2010). He explores how this new enthusiasm for local music involved government policy, global culture industries, and the rise of the creative industries as modes of national branding and promotion.

The videogames market generates more money than music and films combined and New Zealanders are developing and using this media in complex ways. Huni Mancini discusses a te reo Māori mobile game, Māori Pā Wars (2017), which draws on history and kaupapa Māori methodology to impart mātauranga Māori by immersing the player in the past and the present. Mancini situates the fluidity of Indigenous 'authenticity' in time and place when ideas about binaries such as local/global and reality/virtual are rapidly changing and complicating. Reuben Woods brings us back from the virtual and global to the very real and local situation of post-earthquake Christchurch and its urban art landscapes. Connecting post-quake conditions to Christchurch's history of (or lack of) street culture, Woods examines the many roles of art in reconstituting the city and how these are contested. The fluid nature of the art itself (graffiti, murals, etc.) and the rebuilding of the cityscape raise issues of memory, history, ownership and control. The future roles of urban art in the city remain open ended.

The editors of Backstory hope that you enjoy this new issue and that it stimulates more research and excavation into the rich histories of New Zealand's media, design, and art. We also wish our readers a happy 2019.

\section{Peter Hoar}

On behalf of the BackStory editorial team 